Rev. Bras. Saúde Prod. Anim., Salvador, v.19, n.1, p.1-10 jan./mar., 2018 http://dx.doi.org/10.1590/S1519-99402018000100001

\title{
Chemical, physical and biological changes of white oat ensiled with different
} additives

\author{
Alterações químicas, físicas e biológicas da aveia branca ensilada com diferentes \\ aditivos
}

\author{
GARCEZ NETO, Américo Fróes ${ }^{1 *}$; SILVA, Janielen da ${ }^{2}$; SANTOS, Tiago Machado \\ dos $^{1}$; FERNANDES, Sergio Rodrigo ${ }^{1}$; NASCIMENTO, Eduardo Michelon ${ }^{1}$
}

\author{
${ }^{1}$ Universidade Federal do Paraná, Palotina, Paraná, Brasil. \\ ${ }^{2}$ Universidade de São Paulo, Escola Superior de Agricultura Luiz de Queiroz, Piracicaba, São Paulo, Brasil. \\ *Endereço para correspondência: americo.garcez@ufpr.br
}

\section{SUMMARY}

This study evaluated the addition of inoculants on the aerobic stability, nutritional value, and fermentation and microbiological profiles of white oat silages (Avena sativa L.). The trial was carried out in a completely randomized design with three treatments and six replicates. The treatments consisted of three ensiling approaches: oat $(\mathrm{O})$; oat with homofermentative bacterial inoculant (OB); and oat with bacterialenzymatic inoculant (OBE). The aerobic stability was 9 days for silage $O$ and 14 days for silages $\mathrm{OB}$ and OBE. The non-fiber carbohydrates (NFC) decreased (16.67 to $14.05 \% \mathrm{DM}$ ) and the crude protein (CP) did not change (mean of $8.98 \%$ DM) during the aerobic exposure in all silages. The buffering capacity (BC) decreased, while $\mathrm{pH}$ and the ammonia nitrogen $\left(\mathrm{NH}_{3}-\mathrm{N}\right)$ increased during the aerobic exposure in all silages. Independent from the aerobic exposure period, $\mathrm{BC}$ of $\mathrm{OBE}$ silage was higher than O silage (29.67 vs. $24.80 \mathrm{meq} / 100 \mathrm{~g}$ DM). Lactic acid bacteria count in OB silage (7.83 log CFU/g) was higher than in O and OBE silages (5.24 log CFU/g, on average). Also, the OB silage showed high enterobacteria count compared to OBE silage (2.49 vs. 0.76 log CFU/g). The inoculation with Lactobacillus plantarum, Pediococcus acidilactici and amylase enzyme at the dose of $1 \times 10^{5} \mathrm{CFU} / \mathrm{g}$ does not improve the aerobic stability, nutritional value and the fermentation and microbiological profiles of oat silages.

Keywords: bacteria, ensiling, enzyme, inoculant, winter crop

\section{RESUMO}

Objetivou-se através deste estudo avaliar o efeito da adição de inoculantes sobre a estabilidade aeróbia, a composição químico-bromatológica, o padrão de fermentação e o perfil microbiológico da silagem de aveia branca (Avena sativa L.). O delineamento foi inteiramente casualizado, com três tratamentos e seis repetições. Os tratamentos foram três formas de ensilagem: aveia (A); aveia com inoculante bacteriano homofermentativo (AB); e aveia com inoculante bacterianoenzimático (ABE). A estabilidade aeróbia foi de 9 dias para a silagem A e 14 dias para as silagens $\mathrm{AB}$ e $\mathrm{ABE}$. $\mathrm{O}$ teor de carboidratos não fibrosos (CNF) diminuiu (16,67 para $14,05 \%$ MS), enquanto o teor de proteína bruta $(\mathrm{PB})$ não foi alterado (média de 8,98\% MS) no período de aerobiose em todas as silagens. A capacidade tampão (CT) diminuiu, enquanto o $\mathrm{pH}$ e a concentração de nitrogênio amoniacal $\left(\mathrm{N}-\mathrm{NH}_{3}\right)$ aumentaram no período de aerobiose em todas as silagens. Independente do período de aerobiose, a $\mathrm{CT}$ da silagem $\mathrm{ABE}$ foi maior do que a silagem $\mathrm{A}$ (29,67 vs. 24,80 meq/100 g MS). A contagem de bactérias ácido láticas na silagem $\mathrm{AB}(7,83 \mathrm{log}$ $\mathrm{UFC} / \mathrm{g}$ ) foi maior do que nas silagens $\mathrm{A}$ e $\mathrm{ABE}$ (média de 5,24 log UFC/g). A silagem AB apresentou maior contagem de enterobactérias que a silagem $\mathrm{ABE}(2,49$ vs. 0,76 log UFC/g). A inoculação com bactérias homofermentativas $\mathrm{e}$ com a enzima amilase na dose de $1 \times 10^{5} \mathrm{UFC} / \mathrm{g}$ não melhora a estabilidade aeróbia, a composição químico-bromatológica, o padrão de fermentação e o perfil microbiológico da silagem de aveia branca.

Palavras-chave: bactéria, cultura de inverno, ensilagem, enzima, inoculante 


\section{INTRODUCTION}

Corn and sorghum ensiling between late summer and early fall is an alternative to maximize forage supply during winter in southern Brazil. However, these crops destined to the production of silage compete with the commercial production of grains, among them corn itself (MEINERZ et al., 2015). In addition, the silage of these materials presents high cost per unit of dry matter (ZAMARCHI et al., 2014).

In this context, winter cereal silage can be a way to overcome periods of low forage availability and decrease the production costs during winter. Among these cereals, white oats (Avena sativa L.) is an excellent option, because besides being used for grazing, it can be preserved as silage, partially replacing corn and sorghum (ZAMARCHI et al., 2014).

During the vegetative stage, which occurs during fall, winter crops have high nutritional value and provide good animal performance. However, at this stage the moisture content of the plants is very high, favoring the proliferation of undesirable microorganisms, such as clostridia, through excessive fermentation of the material, the occurrence of proteolysis and the production of effluents from the silage (PARIS et al., 2015).

Fermentation-enhancing additives can be used to improve the fermentation process and minimize losses in winter crop silages (XIE et al., 2012). Inoculants containing lactic acid bacteria promote a faster $\mathrm{pH}$ drop, allow preservation of silage material, minimize nutrient losses and inhibit the growth of Clostridium bacteria. The addition of enzymes as amylase at the ensiling may also increase the production of lactic acid due to the highest release of fermentation substrate from the hydrolysis of starch present in the cereal grains (NIKKHAH, 2013).
Although white oat silage is already a food option for cattle in southern Brazil, there is still little information on the fermentative and qualitative characteristics of this type of silage. The goal of this study was to evaluate the aerobic stability, the chemical composition, the fermentation pattern and the microbiological profile of the silage of fresh white oat and white oat ensiled with two types of additives (bacterial and bacterial-enzymatic).

\section{MATERIAL AND METHODS}

The experiment was conducted at the Federal University of Paraná (Universidade Federal do Paraná UFPR), located in Palotina, State of Paraná. The study material was White Oat IPR 126 (Avena sativa L.), sown between March and April at the Agricultural Institute of Paraná (Instituto Agronômico do Paraná - IAPAR), Palotina Experimental Station. The crop was harvested after 110 days of growth. After harvesting, the material was chopped into approximately $20 \mathrm{~mm}$ particles and ensiled in PVC tubes with $150 \mathrm{~mm}$ diameter and $600 \mathrm{~mm}$ high under a pressure of $400 \mathrm{~kg}$ of fresh matter $(\mathrm{FM}) / \mathrm{m}^{3}$.

The design was completely randomized, with three treatments and six replicates. The treatments were characterized by three types of ensiling: oats $(\mathrm{O})$; oats with homofermentative bacterial inoculant (Lalsil CL - Lallemand Animal Nutrition), composed of Lactobacillus plantarum (MA 18/5U) and Pediococcus acidilactici (MA $18 / 5 \mathrm{M}$ ) at a dose of $1 \times$ $10^{5} \mathrm{CFU} / \mathrm{g}$ FM (OB); oats with bacterialenzymatic inoculant (Bacto Silo Master Tropical - Katec Agrotécnica LTDA) composed of Lactobacillus plantarum, Pediococcus acidilactici and amylase, at a dose of $1 \times 10^{5} \mathrm{CFU} / \mathrm{g} \mathrm{FM}$ (OBE). The 
inoculants were diluted in distilled water and applied homogeneously in the forage according to the manufacturer's recommendations: for Lalsil CL, 0.2 grams inoculant was used for each $100 \mathrm{~kg}$ FM; for Bacto Silo Master Tropical, 0.2 grams inoculant for each $100 \mathrm{~kg}$ FM. To maintain the same forage moisture content in the three treatments, the volume of distilled water added in the silages with inoculant was added in the control silage.

The silos were opened 108 days after sealed. In order to evaluate the aerobic stability and the fermentation pattern of the silages, two evaluation times were considered: T0 - upon silo opening; T20 twenty days after aerobic exposure.

In the aerobiosis period, the temperatures of the ensiled mass and the ambient were measured daily with thermosensors connected to a data storage unit (HOBO Data Logger $\left.{ }^{\circledR}\right)$. The time for the temperature variation in silos above $2{ }^{\circ} \mathrm{C}$ in relation to the room temperature was adopted as reference for the determination of the breakdown of aerobic stability (TAYLOR \& KUNG JUNIOR, 2002). The results of mean temperature of the ambient and inside the silos, and the variation of the temperature inside the silos in relation to the ambient in the period of aerobic exposure were presented in a descriptive way.

Silage samples were collected at both evaluation times (T0 and T20) and analyzed for nutritional composition and physicochemical characteristics. Samples destined to the analysis of nutritional composition were dehydrated in a forced ventilation oven at $55^{\circ} \mathrm{C}$ for 72 hours. After drying, the samples were ground in a Wiley mill with a $1 \mathrm{~mm}$ mesh sieve. Dry matter (DM), crude protein (CP), ether extract (EE) and ash were determined according to the procedures of the Association of Official Analytical Chemists (AOAC, 1990). Neutral detergent fiber (NDF) and acid detergent fiber (ADF) were determined by the autoclaving technique (PELL \& SCHOFIELD, 1993; DETMANN et al., 2012). Hemicellulose content (HCel) was obtained by the difference between NDF and ADF. Non-fiber carbohydrates (NFC) content was calculated by the equation: $100-(\mathrm{CP}+\mathrm{EE}+\mathrm{NDF}+\mathrm{Ash})$.

To evaluate the physicochemical characteristics of the silages, approximately 150 g FM were collected from each silo. Afterwards, each sample was divided into subsamples to evaluate the following characteristics: buffering capacity (BC) - measured in subsamples of $15 \mathrm{~g}$ according to Playne \& McDonald (1966); pH - evaluated in subsamples of 9 g according to Silva \& Queiroz (2002); electrical conductivity (EC) - measured in subsamples of $25 \mathrm{~g}$ according to Kraus et al. (1999); and ammonia nitrogen $\left(\mathrm{NH}_{3}-\right.$ N) - evaluated in $25 \mathrm{~g}$ subsamples according to the procedures described by AOAC (1990).

For microbiological analysis, $25 \mathrm{~g}$ FM were aseptically taken from each silo. After sampling, $225 \mathrm{~mL}$ saline solution was added to each sample. The solutions were homogenized, diluted $10^{-1}$ to $10^{-5}$ and pour plated in Petri dishes with specific media for the microorganisms studied. Lactic acid bacteria were cultivated on Man, Rogosa and Sharpe agar (MRS) under anaerobic condition at $37^{\circ} \mathrm{C}$ for three days. Enterobacteria were cultivated on Violet Red Bile agar under aerobic condition at $35^{\circ} \mathrm{C}$ for two days.

The nutritional and physicochemical composition data of the silages were analyzed in a split-plot model, with the type of silage assigned to the plot and the initial (T0) and final (T20) days of aerobic exposure period to the sub-plot. The isolated effects of ensiling type and aerobic exposure time, as well as the interaction between the two factors were tested by analysis of variance $(\mathrm{P}=0.10)$, and the means were compared by Tukey's test. Data on the microbiological 
profile of the silages at the time of opening the silos were tested by analysis of variance according to the ensiling type $(\mathrm{P}=0.10)$, and the means were compared by Tukey's test. Statistical analyses were performed in the Statistical Analysis System (SAS), version 9.0.

\section{RESULTS AND DISCUSSION}

Aerobic stability of silage $\mathrm{O}$ was broken with approximately 9 days of aerobic activity, while $\mathrm{OB}$ and $\mathrm{OBE}$ silages maintained stability for up to approximately 14 days (Figure 1).
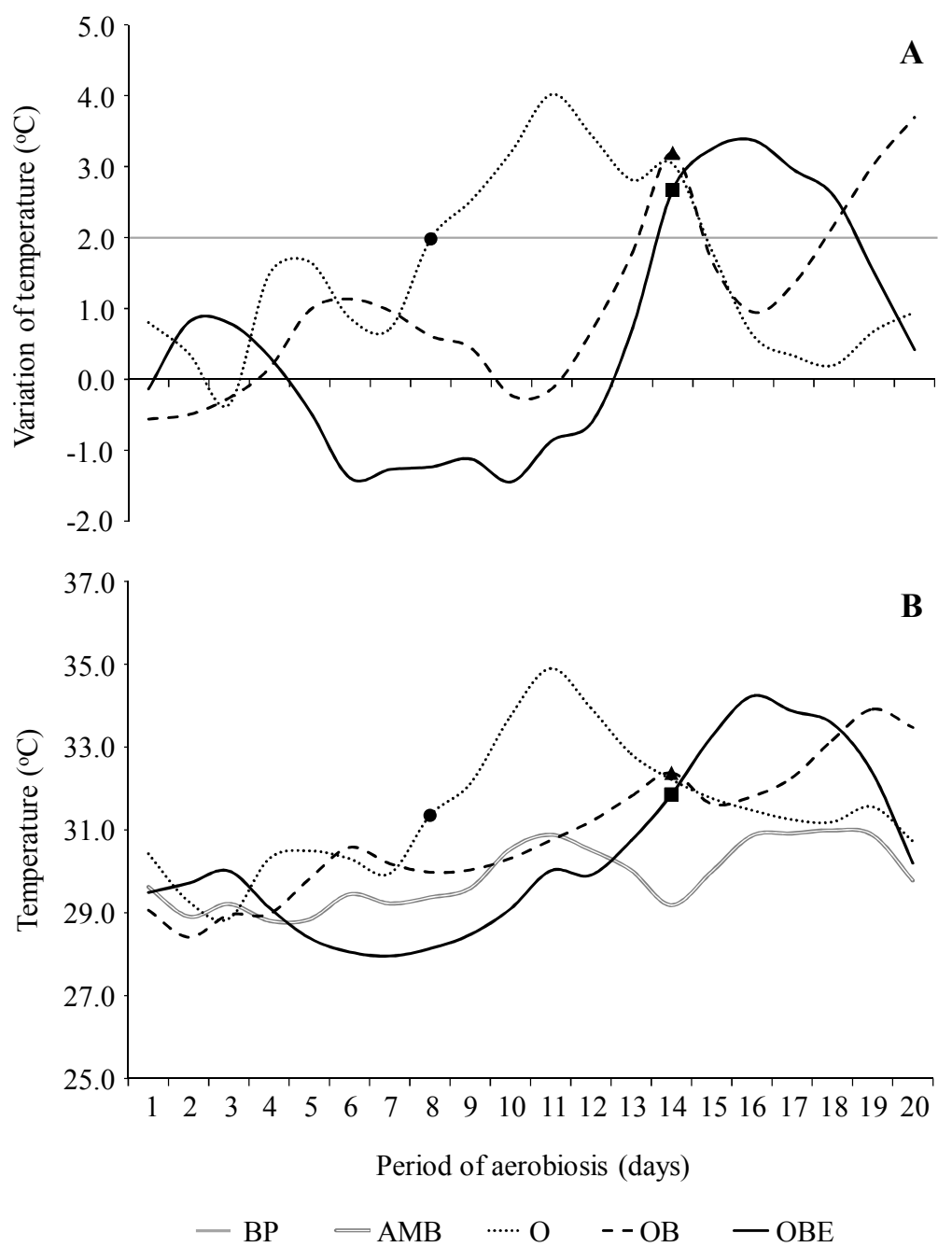

$\mathrm{BP}=$ break point of aerobic stability; $\mathrm{AMB}=$ ambient temperature; $\mathrm{O}=$ oat; $\mathrm{OB}=$ oat with bacterial inoculant composed of Lactobacillus plantarum and Pediococcus acidilactici; OBE = oat with bacterialenzymatic inoculant composed of Lactobacillus plantarum, Pediococcus acidilactici and amylase.

-Break of aerobic stability for O; $\boldsymbol{\Delta}$ Break of aerobic stability for OB; -Break for aerobic stability for OBE.

Figure 1. Variation of temperature (A) and mean temperature inside the silos and in the ambient (B) during the period of aerobiosis for white oat (Avena sativa L.) silages without and with bacterial and bacterialenzymatic inoculants 
Sucu \& Çifci (2016) evaluated two combinations of lactic acid bacteria with enzymes (Pediococcus acidilactici, Lactobacillus plantarum and Streptococcus faecium with the enzymes cellulase, hemicellulase, pentosanase and amylase in the first combination; Pediococcus acidilactici and Lactobacillus plantarum with amylase in the second combination) in triticale silages, and observed better aerobic stability in the material inoculated with the first combination, since the yeast activity was lower in comparison to the other silages.

The treatments influenced the DM content of the silages, where the OBE silage presented lower DM content than O silage, independent of the aerobiosis period (26.79 vs. 27.97\% FM; Table 1). The DM content of OB silage was similar to the others $(27.16 \% \mathrm{FM})$. These results contrast with the results obtained by Keles \& Dermici (2011), who evaluated the use of homofermentative and heterofermentative lactic acid bacteria in triticale silages and found no effect of treatments on the DM content of the ensiled material. This can be explained by the possible increase in the fermentation rate of the ensiled material due to a larger population of microorganisms, resulting in higher production of water in OBE silage. However, this higher fermentation did not improve the ensiling process, as indicated by the physicochemical characteristics of the silages (Table 2). In addition, the higher rate of fermentation may be associated with an increase in the population of undesirable microorganisms, such as clostridia. The fact that the fermentative process of oat silage has not been improved with the use of bacterial and bacterial-enzymatic inoculants may be related to the inefficiency of the inoculated microorganisms in competing with the epiphytic flora of the forage.
The CP content was not influenced by the ensiling types and the aerobic exposure, presenting a mean value of $8.98 \% \mathrm{DM}$ (Table 1). Zahiroddini et al. (2004) analyzed the effect of inoculants and hydrolytic enzymes on the fermentative characteristics and nutritive value of barley silages and observed that the silage containing bacterial inoculant had a higher $\mathrm{CP}$ content (13.2\%) compared to control silage $(11.7 \%)$, silage containing inoculants and enzymes (12.6\%) and silage containing only enzymes $(11.8 \%)$. There was interaction between the ensiling types and the aerobic exposure for the contents of EE, NDF, ADF and ash (Table 1). The NDF and ADF contents of $\mathrm{O}$ and $\mathrm{OB}$ silages were higher at 20 days of aerobic exposure (mean of 68.00 and $36.67 \% \mathrm{DM}$ for NDF and ADF, respectively) compared to the time of opening the silos (mean of 63.79 and $33.53 \%$ DM for NDF and $\mathrm{ADF}$, respectively), which is explained by the consumption of easily fermentable substrates by deteriorating microorganisms in the aerobic period. This is confirmed by the NFC contents that were influenced only by aerobic exposure and reduced from the silo opening time to 20 days of aerobic exposure (16.67 vs. 14.05\% DM). When silage is exposed to oxygen-dependent microorganisms that remained inactive or have low activity, such as aerobic bacteria, molds and yeasts, they are activated and can multiply, leading to substrate oxidation and silage deterioration (McDONALD et al. 1991).

At silo opening, OBE silage had a higher NDF content than the others (65.57 vs. $63.79 \%$ DM, on average, Table 1). One of the effects of the inoculants is the reduction of NDF content due to the higher consumption of hemicellulose during fermentation. 
Table 1. Means and coefficient of variation (CV) for nutritional components of white oat (Avena sativa L.) silages at the time of silos opening (day 0 ) and after the aerobic exposure (day 20)

\begin{tabular}{|c|c|c|c|c|c|c|}
\hline \multirow{2}{*}{ Component $^{1}$} & \multirow{2}{*}{$\begin{array}{c}\text { Time } \\
\text { (days) }\end{array}$} & \multicolumn{3}{|c|}{ Silage $^{2}$} & \multirow{2}{*}{ Mean } & \multirow{2}{*}{$\begin{array}{l}\text { CV } \\
(\%)\end{array}$} \\
\hline & & $\mathrm{O}$ & OB & OBE & & \\
\hline \multirow{3}{*}{$\mathrm{DM}(\% \mathrm{FM})$} & 0 & 28.11 & 26.52 & 26.61 & 27.08 & \multirow{3}{*}{4.43} \\
\hline & 20 & 27.83 & 27.79 & 26.97 & 27.53 & \\
\hline & Mean & $27.97^{\mathrm{a}}$ & $27.16^{\mathrm{ab}}$ & $26.79^{b}$ & 27.31 & \\
\hline \multirow{3}{*}{$\mathrm{CP}(\% \mathrm{DM})$} & 0 & 9.49 & 9.34 & 8.87 & 9.23 & \multirow{3}{*}{10.36} \\
\hline & 20 & 8.75 & 8.29 & 9.16 & 8.73 & \\
\hline & Mean & 9.12 & 8.82 & 9.01 & 8.98 & \\
\hline \multirow{3}{*}{$\mathrm{EE}(\% \mathrm{DM})$} & 0 & $3.65^{\mathrm{bA}}$ & $4.02^{\mathrm{aA}}$ & $3.79^{\mathrm{abA}}$ & $3.82^{\mathrm{A}}$ & \multirow{3}{*}{16.35} \\
\hline & 20 & $2.97^{\mathrm{aB}}$ & $2.84^{\mathrm{aB}}$ & $3.10^{\mathrm{aB}}$ & $2.97^{\mathrm{B}}$ & \\
\hline & Mean & 3.31 & 3.43 & 3.44 & 3.39 & \\
\hline \multirow{3}{*}{ NDF (\% DM) } & 0 & $63.61^{\mathrm{bB}}$ & $63.97^{\mathrm{bB}}$ & $65.57^{\mathrm{aA}}$ & $64.38^{\mathrm{B}}$ & \multirow{3}{*}{3.60} \\
\hline & 20 & $67.52^{\mathrm{aA}}$ & $68.47^{\mathrm{aA}}$ & $66.34^{\mathrm{aA}}$ & $67.44^{\mathrm{A}}$ & \\
\hline & Mean & 65.56 & 66.22 & 65.95 & 65.91 & \\
\hline \multirow{3}{*}{$\mathrm{ADF}(\% \mathrm{DM})$} & 0 & $33.79^{\mathrm{aB}}$ & $33.26^{\mathrm{aB}}$ & $34.24^{\mathrm{aA}}$ & $33.76^{\mathrm{B}}$ & \multirow{3}{*}{5.70} \\
\hline & 20 & $35.93^{\mathrm{abA}}$ & $37.41^{\mathrm{aA}}$ & $35.14^{\mathrm{bA}}$ & $36.16^{\mathrm{A}}$ & \\
\hline & Mean & 34.86 & 35.33 & 34.69 & 34.96 & \\
\hline \multirow{3}{*}{ HCel (\% DM) } & 0 & 29.82 & 30.71 & 31.33 & 30.62 & \multirow{3}{*}{3.93} \\
\hline & 20 & 31.59 & 31.06 & 31.20 & 31.28 & \\
\hline & Mean & 30.70 & 30.88 & 31.27 & 30.95 & \\
\hline \multirow{3}{*}{ NFC (\% DM) } & 0 & 17.84 & 16.64 & 15.54 & $16.67^{\mathrm{A}}$ & \multirow{3}{*}{14.04} \\
\hline & 20 & 13.64 & 13.97 & 14.55 & $14.05^{\mathrm{B}}$ & \\
\hline & Mean & 15.74 & 15.30 & 15.04 & 15.36 & \\
\hline \multirow{3}{*}{ Ash (\% DM) } & 0 & $5.97^{\mathrm{bB}}$ & $6.04^{\mathrm{abB}}$ & $6.24^{\mathrm{aB}}$ & $6.08^{\mathrm{B}}$ & \multirow{3}{*}{6.69} \\
\hline & 20 & $6.91^{\mathrm{aA}}$ & $6.43^{\mathrm{bA}}$ & $6.86^{\mathrm{aA}}$ & $6.73^{\mathrm{A}}$ & \\
\hline & Mean & $6.44^{\mathrm{ab}}$ & $6.23^{\mathrm{b}}$ & $6.55^{\mathrm{a}}$ & 6.41 & \\
\hline
\end{tabular}

${ }^{1} \mathrm{FM}=$ fresh matter; $\mathrm{DM}=$ dry matter; $\mathrm{CP}=$ crude protein; $\mathrm{EE}=$ ether extract; $\mathrm{NDF}=$ neutral detergent fiber; $\mathrm{ADF}=$ acid detergent fiber; $\mathrm{HCel}=$ hemicellulose; $\mathrm{NFC}=$ non-fibrous carbohydrates.

${ }^{2} \mathrm{O}=$ oat; $\mathrm{OB}=$ oat with bacterial inoculant composed of Lactobacillus plantarum and Pediococcus acidilactici; OBE: oat with bacterial-enzymatic inoculant composed of Lactobacillus plantarum, Pediococcus acidilactici and amylase.

Means followed by different lowercase letters in the row and different uppercase letters in the columns differ by Tukey test $(\mathrm{P}<0.10)$.

However, when analyzing the $\mathrm{HCel}$ content, it was found that this was similar among the ensiling types (30.95\% DM, on average, Table 1), indicating that the bacterial-enzymatic inoculant was not effective in reducing the contents of this constituent of the cell wall in oat silage. Ozduven et al. (2010), when evaluating the effects of bacterial inoculants alone or combined with enzymes on triticale silages, found that the silage containing bacterial and enzymatic inoculant had a lower NDF content $(56.8 \% \mathrm{DM})$ than silage without inoculants and silage with bacterial inoculant (60.6\% DM, on average). The same authors observed no effect of the addition of lactic acid bacteria and enzymes on the content of ADF. This can be explained by the lack of activity of the enzymes in promoting the solubilization of the constituents of the cell wall. 
The EE content was lower at 20 days of aerobiosis in all silages (mean of $2.97 \%$ DM, Table 1). However, when the silos were opened, OB silage presented a higher EE content than $\mathrm{O}$ silage (4.02 vs. $3.65 \% \mathrm{DM})$, while OBE silage did not differ from the others $(3.79 \% \mathrm{DM})$. The ash content was higher at 20 days of aerobiosis in all silages (mean of $6.73 \% \mathrm{DM})$. At the time of opening the silos, OBE silage presented a higher ash content than $\mathrm{O}$ silage (6.24 vs. $5.97 \%$ $\mathrm{DM})$, and OB silage was similar to the others $(6.04 \%$ DM). At 20 days of aerobic activity, OB silage presented lower ash content than $\mathrm{O}$ and $\mathrm{OBE}$ silages $(6.43$ vs. $6.89 \%$ DM, on average).

The $\mathrm{pH}$ of the silages was influenced only by the aerobic exposure, being higher at 20 days of aerobiosis compared to the opening time of the silos (8.34 vs. 4.28; Table 2). Aerobic deterioration begins with the action of aerobic yeasts, which use residual soluble carbohydrates or lactic acid for their metabolism (OZDUVEN et al., 2010). In the case of yeasts, deterioration starts because they have the capacity to use these components as substrate for the production of carbon dioxide $\left(\mathrm{CO}_{2}\right)$, water and heat. This causes an increase in the $\mathrm{pH}$ of silage, allowing the growth of undesirable microorganisms that are less tolerant to low $\mathrm{pH}$, such as filamentous fungi and aerobic bacteria. In addition to the loss of DM, degradation of amino acids occurs generating ammonia, which further contributes to $\mathrm{pH}$ elevation (McDONALD et al., 1991).

Table 2. Means and coefficient of variation (CV) for physical-chemical components of white oat (Avena sativa L.) silages at the time of silos opening (day 0 ) and after the aerobic exposure (day 20)

\begin{tabular}{|c|c|c|c|c|c|c|}
\hline \multirow{2}{*}{ Component $^{1}$} & \multirow{2}{*}{ Time (days) - } & \multicolumn{3}{|c|}{ Silage $^{2}$} & \multirow{2}{*}{ Mean } & \multirow{2}{*}{$\begin{array}{l}\mathrm{CV} \\
(\%)\end{array}$} \\
\hline & & $\mathrm{O}$ & OB & OBE & & \\
\hline \multirow{3}{*}{$\mathrm{pH}(1-14)$} & 0 & 4.23 & 4.33 & 4.29 & $4.28^{\mathrm{B}}$ & \multirow{3}{*}{34.41} \\
\hline & 20 & 8.68 & 8.52 & 7.83 & $8.34^{\mathrm{A}}$ & \\
\hline & Mean & 6.46 & 6.42 & 6.06 & 6.31 & \\
\hline \multirow{3}{*}{$\begin{array}{l}\mathrm{BC}(\mathrm{meq} / \\
100 \mathrm{~g} \mathrm{DM})\end{array}$} & 0 & 41.56 & 48.44 & 47.00 & $45.67^{\mathrm{A}}$ & \multirow{3}{*}{66.73} \\
\hline & 20 & 8.04 & 7.39 & 12.33 & $9.25^{\mathrm{B}}$ & \\
\hline & Mean & $24.80^{\mathrm{b}}$ & $27.92^{\mathrm{ab}}$ & $29.67^{\mathrm{a}}$ & 27.46 & \\
\hline \multirow{3}{*}{$\mathrm{EC}(\mathrm{mS} / \mathrm{cm})$} & 0 & 1266.22 & 1280.04 & 1253.93 & 1266.73 & \multirow{3}{*}{8.57} \\
\hline & 20 & 1295.48 & 1319.58 & 1361.55 & 1325.54 & \\
\hline & Mean & 1280.85 & 1299.81 & 1307.74 & 1296.13 & \\
\hline \multirow{3}{*}{$\begin{array}{l}\mathrm{NH}_{3}-\mathrm{N} \\
(\% \text { total } \mathrm{N})\end{array}$} & 0 & $18.97^{\mathrm{bB}}$ & $22.89^{\mathrm{aB}}$ & $21.30^{\mathrm{abB}}$ & $21.05^{\mathrm{B}}$ & \multirow{3}{*}{30.14} \\
\hline & 20 & $40.07^{\mathrm{aA}}$ & $33.30^{\mathrm{aA}}$ & $34.82^{\mathrm{aA}}$ & $36.06^{\mathrm{A}}$ & \\
\hline & Mean & 29.52 & 28.09 & 28.06 & 28.56 & \\
\hline \multicolumn{7}{|c|}{$\begin{array}{l}{ }^{1} \mathrm{BC}=\text { buffering capacity; } \mathrm{DM}=\text { dry matter; } \mathrm{EC}=\text { electrical conductivity; } \mathrm{NH}_{3}-\mathrm{N}=\text { ammonia nitrogen; } \mathrm{N} \\
=\text { nitrogen. } \\
{ }^{2} \mathrm{O}=\text { oat; } \mathrm{OB}=\text { oat with bacterial inoculant composed of Lactobacillus plantarum and Pediococcus } \\
\text { acidilactici; } \mathrm{OBE}=\text { oat with bacterial-enzymatic inoculant composed of Lactobacillus plantarum, } \\
\text { Pediococcus acidilactici } \text { and amylase. } \\
\text { Means followed by different lowercase letters in the row and different uppercase letters in the columns } \\
\text { differ by Tukey test }(\mathrm{P}<0.10) \text {. }\end{array}$} \\
\hline
\end{tabular}


There was an isolated effect of the ensiling types and the aerobic exposure on BC of silages (Table 2). OBE silage presented higher $\mathrm{BC}$ than $\mathrm{O}$ silage (29.67 vs. $24.80 \mathrm{meq} / 100 \mathrm{~g} \mathrm{DM}$ ), while OB silage was similar to the others (27.92 meq/100 g DM). All silages presented lower BC at 20 days of aerobiosis (mean of $9.25 \mathrm{meq} / 100 \mathrm{~g} \mathrm{DM}$ ). In general, BC is low for corn (150 to $250 \mathrm{meq} / 100 \mathrm{~g} \mathrm{DM}$ ), intermediate for grasses (250 to 500 meq/100 g DM) and high for legumes (400 to 600 meq/100 g DM) (McDONALD et al., 1991). The high values of $\mathrm{BC}$ for all silages at the time of opening the silos (mean of $45.67 \mathrm{meq} / 100$ g DM) compared to the values recorded at 20 days of aerobiosis can be attributed to the high $\mathrm{CP}$ content of the oats, which resulted in higher $\mathrm{NH}_{3}-\mathrm{N}$ contents and resistance to $\mathrm{pH}$ drop.

Ammonia odor and the presence of fungi were recorded at the opening of silos, indicating that the fermentation process did not occur satisfactorily. In addition, the $\mathrm{pH}$ values at the time of opening the silos (mean of 4.28, Table 2) were slightly higher than those recommended for the occurrence of adequate fermentation (3.8 and 4.2) (McDONALD et al., 1991). The $\mathrm{NH}_{3}-\mathrm{N}$ contents also show that there was little efficiency in the fermentation process of silages. $\mathrm{NH}_{3}-\mathrm{N}$ values below $10 \%$ in total nitrogen $(\mathrm{N})$ indicate that the fermentation process occurred satisfactorily, which was not observed in the ensiling types evaluated in this study, which presented values higher than $18 \%$ total $\mathrm{N}$ upon silo opening (mean of $21.05 \%$ total N, Table 2).

There was interaction between the ensiling types and the aerobic exposure for $\mathrm{NH}_{3}-\mathrm{N}$ contents, which were higher at 20 days of aerobiosis in all silages (36.06\% total $\mathrm{N}$, Table 2). OB silage presented higher $\mathrm{NH}_{3}-\mathrm{N}$ content at the time of opening the silos in relation to $\mathrm{O}$ silage (22.89 vs. $18.97 \%$ total $\mathrm{N})$. When comparing to OBE silage $(21.30 \%$ total $\mathrm{N}$ ), the $\mathrm{NH}_{3}-\mathrm{N}$ values of the other silages were similar. Ammonia may originate from proteolytic activity of the plant, in which the conversion of true protein into non-protein soluble $\mathrm{N}$ occurs by proteases present in it; and also by deamination caused by microorganisms such as clostridia during the process of silage deterioration.

Lactic acid bacteria counts were higher in $\mathrm{OB}$ silage compared to $\mathrm{O}$ and $\mathrm{OBE}$ silages at silo opening (7.83 vs. $5.24 \mathrm{log}$ $\mathrm{CFU} / \mathrm{g}$ FM, on average, Table 3).

Table 3. Means and coefficient of variation (CV) for bacterial count in the fresh matter (FM) of white oat (Avena sativa L.) silages at the time of silos opening

\begin{tabular}{|c|c|c|c|c|c|}
\hline \multirow{2}{*}{ Bacteria } & \multicolumn{3}{|c|}{ Silage $^{1}$} & \multirow{2}{*}{ Mean } & \multirow{2}{*}{$\begin{array}{l}C V \\
(\%)\end{array}$} \\
\hline & $\mathrm{O}$ & $\mathrm{OB}$ & OBE & & \\
\hline Lactic acid bacteria (log CFU/g FM) & $5.597^{\mathrm{b}}$ & $7.833^{\mathrm{a}}$ & $4.890^{\mathrm{b}}$ & 6.005 & 27.16 \\
\hline Enterobacteria (log CFU/g FM) & $1.531^{\mathrm{ab}}$ & $2.488^{\mathrm{a}}$ & $0.759^{\mathrm{b}}$ & 1.642 & 80.95 \\
\hline
\end{tabular}

${ }^{\mathrm{T}} \mathrm{O}=$ oat; $\mathrm{OB}=$ oat with bacterial inoculant composed of Lactobacillus plantarum and Pediococcus acidilactici; $\mathrm{OBE}=$ oat with bacterial-enzymatic inoculant composed of Lactobacillus plantarum, Pediococcus acidilactici and amylase.

Means followed by different lowercase letters in the row differ by Tukey test $(\mathrm{P}<0.10)$. 
Nevertheless, even with a greater number of lactic acid bacteria, the bacterial inoculant was not efficient in improving the fermentation process of the oat silage, as demonstrated by the $\mathrm{pH}$ values and the $\mathrm{NH}_{3}-\mathrm{N}$ contents reported previously. OBE silage was similar to $\mathrm{O}$ silage for lactic acid bacteria counts $(4.89$ vs. $5.60 \quad$ log CFU/g FM), showing that the dose used $\left(1 \times 10^{5} \mathrm{CFU} / \mathrm{g} \mathrm{FM}\right)$ or the fermentation environment were not suitable for the development of the inoculated bacteria.

Enterobacteria counts were higher in OB silage compared to OBE silage (2.49 vs. $0.76 \log \mathrm{CFU} / \mathrm{g}$ FM, Table 3 ), demonstrating the low efficiency of lactic acid bacteria in producing lactic acid and reducing the $\mathrm{pH}$ rapidly to inhibit the growth of enterobacteria. This group of microorganisms is the main competitor for substrate with lactic acid bacteria at the beginning of the fermentation process. The main fermentation product of the enterobacteria is acetic acid, however, they also produce ammonia through various deamination reactions (McDONALD et al., 1991). The high $\mathrm{CP}$ content of oats, the high $\mathrm{BC}$ and the high $\mathrm{NH}_{3}-\mathrm{N}$ production should have hinder the rapid drop of $\mathrm{pH}$ and the preservation of the ensiled mass.

The use of inoculants composed only of Lactobacillus plantarum and Pediococcus acidilactici or combined with amylase at $1 \times 10^{5} \mathrm{CFU} / \mathrm{g}$ FM does not significantly increase aerobic stability and does not improve nutritional composition, fermentation pattern and microbiological profile of white oat silages.

\section{REFERÊNCIAS}

ASSOCIATION OF OFFICIAL ANALYTICAL CHEMISTS - AOAC. Official methods of analysis. $15^{\text {th }} \mathrm{ed}$. Arlington: AOAC International, 1990. $1117 \mathrm{p}$.

DETMANN, E.; SOUZA, M.A.; VALADARES FILHO, S.C. (Eds.). Métodos para análises de alimentos. Visconde do Rio Branco: Suprema, 2012. 214p.

KELES, G.; DEMIRCI, U. The effect of homofermentative and heterofermentative lactic acid bacteria on conservation characteristics of baled triticale-Hungarian vetch silage and lamb performance. Animal Feed Science and Technology, v.164, n.1-2 p.21-28, 2011.

KRAUS, T.J.; KOEGER, R.G.; STRAUB, R.J.; SHINNERS, K. Leachate conductivity as an index for quantifying level of forage conditioning. American Society of

Agricultural and Biological Engineers, v.42, n.4, p.847-852, 1999.

McDONALD, P.; HENDERSON, A.R.; HERON, S.J.E. The biochemistry of silage. $2^{\text {th }}$ ed. Marlow: Chalcombe Publication, 1991. 340p.

MEINERZ, G.R.; OLIVO, C.J.; NÖRNBERG, J.L.; VIÉGAS, J.; AGNOLIN, C.A.; SCHEIBLER, R.B.; SKONIESK, F.R.; ZIECH, M.F.; QUATRIN, M.P. Utilização da biomassa remanescente de pastagens de estação fria para produção de forragem conservada. Arquivos Brasileiros de Medicina Veterinária e Zootecnia, v.67, n.5, p.1390-1398, 2015. 
NIKKHAH, A. Barley forages for modern global ruminant agriculture: a review. Russian Agricultural

Sciences, v.39, n.3, p.206-213, 2013.

OZDUVEN, M.L.; KURSUN ONAL, Z.; KOC, F. The effects of bacterial inoculants and/or enzymes on the fermentation, aerobic stability and in vitro dry and organic matter digestibility characteristics of triticale silages. Kafkas Üniversitesi Veteriner Fakültesi Dergisi, v.16, n.5, p.751-756, 2010.

PARIS, W.; ZAMARCHI, G.; PAVINATO, P.S.; MARTIN, T.N.

Qualidade da silagem de aveia preta sob efeito de estádios fenológicos, tamanhos de partícula e pré-murchamento.

Revista Brasileira de Saúde e Produção Animal [online], v.16, n.3, p.486-498, 2015.

PELL, A.N.; SCHOFIELD, P. Computerized monitoring of gas production to measure forage digestion in vitro. Journal of Dairy Science, v.76, n.4, p.1063-1073, 1993.

PLAYNE, M.J.; McDONALD, P. The buffering constituents of herbage and of silage. Journal of the Science of Food and Agriculture, v.17, n.6, p.264-268, 1966.

SILVA, D.J.; QUEIROZ, A.C. Análise de alimentos: métodos químicos e biológicos. 3.ed. Viçosa, MG:

Universidade Federal de Viçosa, 2002. $235 p$.

SUCU, E.; ÇIFCI, E.A. Effects of lines and inoculants on nutritive value and production costs of triticale silages.

Revista Brasileira de Zootecnia, v.45, n.7, p.355-364, 2016.
TAYLOR, C.C.; KUNG JUNIOR, L. The effect of Lactobacillus buchneri 40788 on fermentation and aerobic stability of high moisture corn in laboratory silos. Journal of Dairy Science, v.85, p.1526-1532, 2002.

XIE, Z.L.; ZHANG, T.F.; CHEN, X.Z.; LI, G.Z.; ZHANG, J.G. Effects of maturity stages on the nutritive composition and silage quality of whole crop wheat. Asian Australasian Journal of Animal Science, v.25, n.10, p.1374-1380, 2012.

ZAHIRODDINI, H.; BAAH, J.; ABSALOM, W.; McALLISTER, T.A. Effect of an inoculant and hydrolytic enzymes on fermentation and nutritive value of whole crop barley silage. Animal Feed Science and Technology, v.117, n.3 p.317-330, 2004.

ZAMARCHI, G.; PAVINATO, P.S.; MENEZES, L.F.G.; MARTIN, T.N. Silagem de aveia branca em função da adubação nitrogenada e prémurchamento. Semina: Ciências Agrárias, v.35, n.4, p.2185-2196, 2014.

Receipt date: $23 / 08 / 2017$

Approval date: 19/02/2018 